\title{
Menciptakan Kepuasan Dan Loyalitas Pelanggan Dengan Desain Produk Harapan Pelanggan
}

\author{
RONI ANDESPA \\ Sekolah Tinggi Ilmu Ekonomi Riau (STIER) \\ Jln. HR. Subrantas 57 Panam Pekanbaru 28293 Telp. (0761) 63237 \\ E-mail : akbar_stier@yahoo.com
}

\begin{abstract}
The study was conducted in the city of Padang, West Sumatra. With the object of restaurants in the city Padang. Research to examine the influence of restaurant product design to customer satisfaction and customer loyalty. The sample used is 400 customers. The analysis used is the path analyze. Which found that there was indeed a significant influence between product design restaurants in the city of Padang on customer satisfaction, product design in the city of Padang restaurants are affecting customer loyalty, either directly or indirectly, and customer satisfaction in the city of Padang restaurant also affects customer loyalty. From the results of research can be made solutions for the restaurant in Padang, That in designing the products must pay attention and understand what the customer needs and wants.
\end{abstract}

Keywords: Product Design, Restaurant, Satisfaction, Loyalty, Customer

Perkembangan bisnis yang semakin dinamis saat sekarang, membuat semakin banyak perusahaan manufaktur ataupun jasa yang didirikan, yang mendorong tingkat persaingan yang semakin ketat dan sangat kompleks. Dalam perkembangan bisnis, khususnya saat ini di daerah Sumatera Barat yaitu di kota padang, sebagai kota yang sedang berkembang setelah gempa beberapa tahun terakhir, industri ataupun usaha di kota Padang mulai berkembang kembali, disamping itu persaingan usaha ataupun dagang kembali hidup pada masing-masing sektor. Maka pada situasi dan kondisi persaingan usaha seperti ini menuntut kejelian dari pihak perusahaan dan pemilik usaha untuk melihat perkembangan keinginan dan kebutuhan konsumen/pelanggan, dimana hal ini yang membuat pimpinan perusahaan sulit didalam menyusun strategi dalam memenangkan persaingan. Dimana kepuasan pelanggan sangat diutamakan, sehingga dapat memperoleh keuntungan yang diharapkan untuk membiayai kelangsungan hidup bisnis.

Dalam perkembangannya, usaha di kota Padang apakah di sektor manufaktur ataupun sektor jasa, seperti pendidikan, pariwisata, transportasi, hiburan dan perhotelan. Beberapa sektor ini saja terlihat tingkat persaingan yang cukup ketat dan kompleks, sehingga untuk memenangkan persaingan dipengaruhi oleh penggunaan teknologi yang canggih dan didukung sumber daya manusia yang tersedia serta berkompeten, diantara usaha yang bersaing ketat itu adalah perusahaan yang bergerak di bidang rumah makan. Pada perkembangannya saat ini, peranan rumah makan semakin besar. Hal ini terlihat dengan semakin bertambahnya dan berkembangnya jumlah rumah makan di sekitar kota Padang, Sehingga persaingan sesama perusahaan yang sejenis semakin tajam.

Keadaan pasar yang berlaku saat ini bukan lagi pasar penjual tetapi menjadi pasar pembeli, dimana penjual yang mencari pembeli, bukan pembeli yang mencari penjual, konsumen dalam hal ini adalah raja yang harus dilayani secara baik. Secara umum perusahaan menerapkan strategi bisnis kombinasi antara strategi offensive dan defensive. Dimana strategi offensive perlu ditujukan untuk meraih atau memperoleh pelanggan baru untuk meningkatkan pangsa pasar. Sedangkan strategi defensive berusaha untuk mengurangi kemungkinan konsumen yang lari dan beralihnya konsumen atau pelanggan perusahaan ke pesaing. 
Strategi untuk mencapai dan menciptakan kepuasan pelanggan dan loyalitas pelanggan menyebabkan perusahaan harus berusaha keras dan mengeluarkan biaya yang cukup tinggi dalam usaha merebut pelanggan atau konsumen yang setia atau loyal kepada perusahaan. Dampak kepuasan pelanggan terhadap loyalitas konsumen dan pembelian ulang berbedabeda setiap perusahaan. Pelanggan yang puas cenderung menjadi pelanggan yang loyal.

Di dalam usaha rumah makan, bukan semata-mata menyediakan makanan dan minuman tetapi juga menyediakan berbagai kelebihan fasilitas yang mendukung kenyamanan konsumen atau pelanggan. Kelebihan-kelebihan atribut yang dimiliki adalah suatu cara untuk menarik konsumen, tetapi walaupun demikian belum tentu rumah makan di kota Padang memiliki atribut yang dapat memenuhi kepuasan konsumen. Hal ini disebabkan karena kebutuhan dan keinginan itu tidak akan berhenti begitu saja, begitu konsumen mendapatkan kepuasannya.

Merupakan sifat dasar manusia itu sendiri, bahwa manusia tidak akan pernah puas terhadap suatu hal. Setelah mendapatkan yang satu, menginginkan yang lainnya, begitu seterusnya. Sehingga seorang produsen haruslah selalu bisa memantau perkembangan yang terjadi, memantau perubahan lingkungan dan harus tanggap terhadap keinginan konsumen, serta selalu berusaha untuk bisa memberikan kepuasan kepada konsumen.

Oleh karena itu, sebaiknya rumah makan di kota Padang selalu memperhatikan kebutuhan dan keinginan konsumen dengan melakukan riset pasar. Hasilnya akan dijadikan sebagai dasar untuk keputusan dalam meningkatkan atau memperbaiki keunggulan perusahaan agar bisa berkompetitif secara aktif, dan usaha pemasaran pun dapat dilakukan dengan perencanaan yang efektif dan terkoordinasi. Sehingga, walaupun saat ini perusahaan mempunyai banyak pesaing, tidak akan membuat para konsumen atau pelanggan untuk berubah pikiran bila mendapat tawaran yang lebih baik. Karena konsumen yang amat puas lebih sukar untuk merubah pikirannya. Kepuasan tinggi akan menciptakan kelekatan emosional terhadap perusahaan, bukan hanya preferensi rasional, tetapi juga akan menciptakan loyalitas pelanggan yang tinggi. Apakah pelanggan akan puas setelah pembelian tergantung pada kinerja penawaran sehubungan dengan harapan pelanggan.

Kepuasan

Secara umum definisi kepuasan pelanggan yang dikemukakan oleh Philip Kotler (2001), sebagai berikut : "Kepuasan adalah perasaan senang atau kecewa seseorang yang berasal dari perbandingan antara kesannya terhadap kinerja (atau hasil) suatu produk dan harapan-harapannya".

Seperti dijelaskan dalam definisi di atas, kepuasan merupakan fungsi dari kesan kinerja dan harapan. Jika kinerja berada dibawah harapan, pelanggan tidak puas. Jika kinerja memenuhi harapan, pelanggan puas. Jika kinerja melebihi harapan, pelanggan amat puas atau senang.

Untuk perusahaan yang berwawasan pelanggan, kepuasan merupakan sasaran sekaligus kiat pemasaran. Perusahaan yang mencapai tingkat kepuasan pelanggan yang tinggi, dapat memastikan bahwa pasar sasaran akan tahu juga tentang hal itu.

Walaupun perusahaan atau organisasi yang berorientasi dan berwawasan pelanggan ingin mencapai kepuasan yang tinggi, namun perusahaan juga harus memperhatikan hal-hal berikut ini:

a. Perusahaan dapat menghentikan kepuasan pelanggan dengan cara merumuskan harga atau meningkatkan pelayanan, namun akibatnya laba perusahaan dapat turun.

b. Perusahaan mungkin dapat menghentikan keuntungan bagi para pelanggan dengan cara, misalnya memperbaiki kualitas produk atau menanamkan modal lebih banyak di bagian riset dan pengembangan.

c. Banyak orang yang mempunyai kepentingan dalam perusahaan termasuk karyawan, penyalur, pemasok dan pemegang saham. 
Dengan kata lain, perusahaan yang berwawasan pelanggan boleh saja memberikan kepuasan yang tinggi kepada pelanggan, asalkan juga dapat memberikan setidak-tidaknya tingkat kepuasan yang dapat diterima oleh pihak-pihak lain yang berkepentingan sesuai batasan jumlah sumber dayanya.

Dan pada dasarnya tujuan dari suatu bisnis adalah kepuasan pelanggan dapat memberikan manfaat, diantaranya hubungan antara perusahaan dan pelanggannya menjadi harmonis, memberikan dasar yang baik bagi pembelian ulang dan terciptanya loyalitas pelanggan.

Loyalitas

Orang yang dalam jangka panjang hanya melakukan pembelian terhadap suatu perusahaan atau merek tertentu yang telah memberikan kepuasan yang tinggi, akan mengakibatkan pelanggan loyal dan memberikan keuntungan yang tinggi bagi perusahaan. Karena orang tersebut tidak akan mudah terpengaruh dengan adanya tawaran yang lebih baik dari perusahaan lain (pesaing). Definisi yang dikemukakan oleh Philip Kotler (2001) tentang loyalitas, adalah sebagai berikut: "Loyalitas adalah suatu tingkat kecenderungan psikologis dari sikap dan perilaku konsumen yang positif, konsisten dan berulang-ulang untuk melakukan suatu aktivitas dirinya yang memiliki kekuatan kesetiaan pada berbagai referensi yang dihadapinya untuk tetap memilih hal yang berupa atau setidaknya beda dari atribut-atribut yang telah dimiliki”.

Dari definisi diatas, dapat diambil suatu kesimpulan bahwa dua aspek yang paling penting dalam loyalitas adalah sikap konsumen dan perilaku konsumen.

Sikap merupakan sesuatu yang mengarah pada tujuan yang dihadapi dalam bentuk tindakan. Sedangkan perilaku adalah interaksi dinamis antara pengaruh dan kognisi di mana manusia melakukan aspek pertukaran dalam hidup mereka atau dalam hidup konsumen.

Dengan demikian, mempertahankan konsumen yang mempunyai sifat dan perilaku yang loyal terhadap perusahaan akan lebih menguntungkan dibanding mencari konsumen yang baru. Untuk membuat pelanggan loyal terhadap suatu jasa atau produk yang ditawarkan oleh perusahaan, maka perusahaan harus bisa menciptakan image positif terhadap kombinasi atributatribut yang akan ditawarkan. Dengan demikian, strategi dari atribut produk ini akan menentukan image, sikap dan perilaku konsumen yang pada akhirnya akan mempengaruhi loyalitas konsumen.

Orang yang sangat puas atau senang akan memiliki ikatan emosional dengan imagenya yang positif, baik persepsi, prestise, konsep dirinya, dan bukan hanya pada preferensi rasionalnya saja. Sehingga inilah yang menyebabkan loyalitas pelanggan yang tinggi.

Atribut Produk

Atribut produk adalah suatu komponen yang merupakan sifat-sifat produk yang menjamin agar produk tersebut dapat memenuhi kebutuhan dan keinginan yang diharapkan oleh konsumen atau pembeli. Setiap produk mempunyai atribut atau sifat yang berbeda, dari atribut inilah suatu produk akan dipandang oleh konsumen. Konsumen akan bervariasi dalam menentukan mana dari atribut-atribut yang menurut pertimbangan mereka relevan, dan mereka akan menaruh perhatian terbesar pada atribut-atribut yang berhubungan dengan kebutuhan mereka.

Desain Produk

Desain merupakan penampilan suatu produk yang membedakan produk perusahaan dengan produk perusahaan pesaing. Barang atau produk harus didesain menarik dan sesuai dengan keinginan pasar sehingga produk tersebut dapat menarik keinginan konsumen untuk membeli. Pada rumah makan desain produk ini termasuk citra rasa masakan yang dihidangkan kepada pelanggan, keragaman jenis masakan, servis tambahan yang diberikan ataupun kualitas pelayanan secara umum yang berbeda dari pesaing-pesaing yang ada.

Analisis Jalur

Penelitian menggunakan analisis jalur. Analisis jalur ialah suatu teknik untuk menganalisis hubungan sebab akibat yang 
terjadi pada regresi berganda jika variabel bebasnya mempengaruhi variabel tergantung tidak hanya secara langsung, tetapi juga secara tidak langsung. Analisis jalur model trimming adalah model yang digunakan untuk memperbaiki suatu model struktur analisis jalur dengan cara mengeluarkan dari model variabel eksogen yang koefisien jalurnya tidak signifikan. Jadi Model trimming terjadi ketika koefisien jalur diuji secara keseluruhan ternyata ada variabel yang tidak signifikan. Cara menggunakannya dengan menghitung ulang koefisien jalur tanpa menyertakan variabel eksogen yang koefisien jalurnya tidak signifikan. Model yang digunakan di dalam penelitian adalah sebagai berikut:

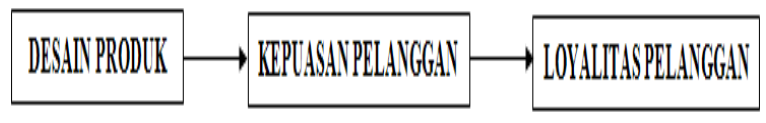

Gambar 1. Model Penelitian

Hipotesis yang dalam penelitian adalah sebagai berikut:

$\mathrm{H}_{1}=$ Diduga desain produk rumah makan di kota Padang mempengaruhi kepuasan pelanggan.

$\mathrm{H}_{2}=$ Diduga desain produk rumah makan di

kota Padang mempengaruhi loyalitas pelanggan, baik secara langsung maupun tidak langsung.

$\mathrm{H}_{3}=$ Diduga kepuasan pelanggan rumah makan di kota Padang mempengaruhi loyalitas pelanggan.

\section{METODE}

Populasi yang digunakan adalah seluruh pelanggan rumah makan dikota Padang, Sumatera Barat. Dimana Sampel dalam penelitan yang digunakan adalah sebanyak 400 pelanggan yang ada, teknik pengambilan sampel yang digunakan adalah metode non probability sampling dengan Convenience sampling, mengingat dimana jumlah populasi yang cukup besar, maka setiap pelanggan yang mudah untuk ditemui, dan rasanya bisa untuk menjadi sampel, maka berhak untuk menjadi responden. Hal ini dilakukan untuk diagnosis situasi secara cepat dan bersifat sederhana serta mudah, karena adanya keterbatasan waktu dalam penelitian.

Data yang digunakan adalah data primer yang diperoleh melalui penyebaran kuesioner kepada responden yang dijadikan sampel dengan pertanyaan tertutup dimana skala pengukurannya menggunakan skala 1 sampai dengan 5 (skala likert). Dimana angka 1 mewakili Sangat Tidak Setuju (STS) sampai dengan angka 5 mewakili Sangat Setuju (SS). Alat analisa yang digunakan adalah dengan menggunakan analisis jalur, dengan pengolahan data dibantu software SPSS versi 15.

Analisis data yang sudah terkumpul dilakukan dengan menggunakan analisis regresi dan analisis jalur model trimming. Pada model dilakukakan pengujian dengan dua Sub-Struktur yaitu:

Struktur 1

Struktur 2

$$
\mathrm{Y}=\rho \mathrm{YX}+\rho_{\mathrm{Y}} \boldsymbol{\varepsilon}_{1}
$$

$$
Z=\rho z x+\rho z \varepsilon_{2}
$$

Keterangan:

$\mathrm{X}=$ Desain Produk

$\mathrm{Y}=$ Kepuasan Pelanggan

$\mathrm{Z}=$ Loyalitas Pelanggan

\section{HASIL}

Setelah kuesioner yang disebarkan kepada responden telah diisi dan telah terkumpul, sehingga didapatkanlah kuesioner yang layak untuk diolah, yaitu sebanyak 400 sampel dari populasi yang ada.

Dilakukanlah analisis terhadap sampel untuk membuktikan hipotesis, pengolahan data yang sudah ditabulasikan kemudian diolah dengan menggunakan software statistik yaitu SPSS versi 15 . Dimana hasil analisis dengan menggunakan regresi dan analisis jalur model trimming, dengan pengolahan software SPSS dapat dilihat pada output komputer dibawah ini. 
Tabel 1. Output SPSS Model Summary Variabel Desain Produk Terhadap Kepuasan Pelanggan, Data Olahan SPSS

Model Summary

\begin{tabular}{|l|r|r|r|r|}
\hline Model & $R$ & R Square & $\begin{array}{r}\text { Adjusted } \\
\text { R Square }\end{array}$ & $\begin{array}{r}\text { Std. Error of } \\
\text { the Estimate }\end{array}$ \\
\hline 1 & $955^{\mathrm{a}}$ & .912 & .911 & .11611 \\
\hline
\end{tabular}

a. Predictors: (Constant), Desain Produk

Dari tabel Model Summary dapat dilihat nilai $\mathrm{R}$ Square menunjukan bahwa variabel desain produk mampu menjelaskan variabel kepuasan pelanggan sebesar 91,2\%, sedangkan sisanya sebesar $8,8 \%$ dipengaruhi oleh variabel/faktor di luar penelitian. Dimana nilai $\mathrm{R}=0,955$ artinya hubungan antara desain produk terhadap kepuasan pelanggan adalah kuat yaitu sebesar $95,5 \%$.

Tabel 2. Output SPSS Coefficients Variabel Desain Produk Terhadap Kepuasan Pelanggan, Data Olahan SPSS

\section{Coefficients ${ }^{3}$}

\begin{tabular}{|c|c|c|c|c|c|c|}
\hline \multirow{2}{*}{\multicolumn{2}{|c|}{ Model }} & \multicolumn{2}{|c|}{$\begin{array}{c}\text { Unstandardized } \\
\text { Coefficients }\end{array}$} & \multirow{2}{*}{ 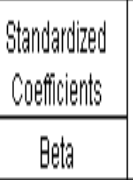 } & \multirow[b]{2}{*}{1} & \multirow[b]{2}{*}{ sig. } \\
\hline & & $\theta$ & Sitd Error & & & \\
\hline 1 & (Constant) & .786 & .052 & & 15.099 & .000 \\
\hline & Dessain Produk & .822 & .013 & .955 & 64.101 & .000 \\
\hline
\end{tabular}

a. Dependent Variable: Kepuasan Pelangagan

Tabel Coefficients Variabel desain produk terhadap kepuasan pelanggan memperlihatkan nilai sig. $0,000(<0,05)$, ini berarti terdapat pengaruh yang signifikan antara desain produk dengan kepuasan pelanggan.

Tabel 2 juga memperlihatkan hasil koefisien jalur antar variabel dan analisis regresi variabel penelitian, dimana nilai koefisien $\rho$ Desain Produk - Kepuasan Pelanggan adalah 0,955 .
Tabel 3. Output SPSS Correlations Variabel Desain Produk Terhadap Kepuasan Pelanggan, Data Olahan SPSS

Correlations

\begin{tabular}{|ll|r|r|}
\hline & & $\begin{array}{r}\text { Desain } \\
\text { Produk }\end{array}$ & $\begin{array}{r}\text { Kepuasan } \\
\text { Pelanggan }\end{array}$ \\
\hline Desain Produk & Pearson Correlation & 1 & $.955^{\circ+}$ \\
& Sig. (2-tailed) & & .000 \\
& $N$ & 400 & 400 \\
\hline Kepuasan Pelanggan & Pearson Correlation & $.955^{*+}$ & 1 \\
& Sig. (2-tailed) & .000 & \\
& $N$ & 400 & 400 \\
\hline
\end{tabular}

*. Correlation is significant at the 0.01 level (2-tailed).

Maka besarnya jalur besarnya koefisien diteminan (konstribusi) Desain produk terhadap Kepuasan adalah sebagai berikut ini:

$R^{2}=(\rho Y X) *(r Y X)$

$R^{2}=(0,955) *(0,955)$

$R^{2}=0,912$

Tabel 4. Output SPSS Model Summary Variabel Desain Produk dan Kepuasan pelanggan Terhadap Loyalitas Pelanggan, Data Olahan SPSS

Model Summary

\begin{tabular}{|c|c|c|c|c|}
\hline Model & $R$ & R Square & $\begin{array}{l}\text { Adjusted } \\
\text { RSquare }\end{array}$ & $\begin{array}{l}\text { Std. Error of } \\
\text { the Estimate }\end{array}$ \\
\hline 1 & $.973^{\mathrm{a}}$ & .946 & .946 & .09237 \\
\hline
\end{tabular}

Tabel Model Summary menunjukan nilai $\mathrm{R}$ Square sebesar 0,946, ini berarti variabel desain produk dan kepuasan pelanggan mampu menjelaskan variabel loyalitas pelanggan sebesar 94,6\%, sedangkan sisanya sebesar $5,4 \%$ dipengaruhi oleh variabel/faktor di luar penelitian. Dimana nilai $\mathrm{R}=0,973$ artinya hubungan antara desain produk dan kepuasan pelanggan terhadap loyalitas pelanggan adalah kuat yaitu sebesar $97,3 \%$. 
Tabel 5. Output SPSS Coefficients Variabel Desain Produk dan Kepuasan Pelanggan Terhadap Loyalitas Pelanggan, Data Olahan SPSS Coefficients ${ }^{\mathrm{a}}$

\begin{tabular}{|c|c|c|c|c|c|c|}
\hline \multirow[b]{2}{*}{ |Model } & & \multicolumn{2}{|c|}{$\begin{array}{l}\text { Unstandardized } \\
\text { Coefficientis }\end{array}$} & \multirow{2}{*}{$\begin{array}{l}\text { Standardized } \\
\text { Coefficients }\end{array}$} & \multirow[b]{2}{*}{1} & \multirow[b]{2}{*}{ sig. } \\
\hline & & $\theta$ & Sitd Error & & & \\
\hline & (Constantit) & .426 & .052 & & 8.204 & .000 \\
\hline & Desain Produk & .582 & 034 & .666 & 16.947 & .000 \\
\hline & Kepuasan Pelangugan & .320 & .040 & .316 & 8.033 & .000 \\
\hline
\end{tabular}

a. Dependent Variable: Loyallias Pelanngaan

Tabel Coefficients Variabel desain produk terhadap loyalitas pelanggan memperlihatkan nilai sig. 0,000 $(<0,05)$, ini berarti terdapat pengaruh yang signifikan antara desain produk terhadap loyalitas pelanggan.

Variabel kepuasan pelanggan terhadap loyalitas pelanggan adalah 0,000 $(<0,05)$, dimana menunjukan pengaruh yang signifikan antara kepuasan pelanggan dengan kepuasan pelanggan.

Tabel juga memperlihatkan hasil koefisien jalur antar variabel dan analisis regresi variabel penelitian, dimana nilai koefisien $\rho$ Desain Produk - Loyalitas Pelanggan adalah 0,666 , nilai koefisien $\rho$ Kepuasan Pelanggan - Loyalitas Pelanggan adalah 0,316 .

Tabel 6. Output SPSS Correlations Variabel Desain Produk dan Kepuasan Pelanggan Terhadap Loyalitas Pelanggan, Data Olahan SPSS

Correlations

\begin{tabular}{|c|c|c|c|c|}
\hline & & $\begin{array}{l}\text { Desain } \\
\text { Produk }\end{array}$ & $\begin{array}{l}\text { Kepuasan } \\
\text { Pelanggan }\end{array}$ & $\begin{array}{l}\text { Loyalitas } \\
\text { Pelanggan }\end{array}$ \\
\hline \multirow[t]{3}{*}{ Desain Produk } & Pearson Correlation & 1 & $.955^{\text {\#x }}$ & $.968^{*}$ \\
\hline & Sig. (1-tailed) & & .000 & .000 \\
\hline & $N$ & 400 & 400 & 400 \\
\hline \multirow[t]{3}{*}{ Kepuasan Pelanggan } & Pearson Correlation & $.955^{\#+}$ & 1 & $.952^{*}$ \\
\hline & Sig. (1-tailed) & .000 & & .000 \\
\hline & $N$ & 400 & 400 & 400 \\
\hline \multirow[t]{3}{*}{ Loyalitas Pelanggan } & Pearson Correlation & $.968^{*+1}$ & $.952^{*+1}$ & 1 \\
\hline & Sig. (1-tailed) & .000 & .000 & \\
\hline & $N$ & 400 & 400 & 400 \\
\hline
\end{tabular}

"*. Correlation is significant at the 0.01 level (1-tailed).

Jadi besarnya jalur besarnya koefisien diteminan (konstribusi) Desain produk dan Kepuasan terhadap Loyalitas adalah : $R^{2}=(\rho \mathrm{ZX}) *(r \mathrm{ZX})+(\rho \mathrm{ZY}) *(r \mathrm{ZY})$
$R^{2}=(0,666) *(0,968)+(0,316) *(0,952)$

$R^{2}=(0,645)+(0,301)$

$R^{2}=0,946$

Total Pengaruh Variabel Eksogen Terhadap Variabel Endogen

Dalam menguraikan total pengaruh variabel eksogen terhadap variabel endogen dicari dulu pengaruh langsung (Direct Effect$\mathrm{DE}$ ), dan pengaruh tidak langsung (Indirect Effect-IE), total pengaruh didapatkan dari dari penjumlahan koefisien DE dan IE.

Total Pengaruh Desain Produk terhadap Loyalitas Pelanggan $=\rho z X+\rho Y x$ pzY

$$
\begin{aligned}
& \text { DE }+\mathrm{IE} \\
& \begin{aligned}
\mathrm{DE} & =0,666(\text { signifikan }) \\
\mathrm{IE} & =0,955^{*} 0,316(\text { signifikan }) \\
& =0,301
\end{aligned} \\
& \begin{aligned}
\text { Total Pengaruh } & =\rho \mathrm{ZX}+\rho \mathrm{YX} \rho \mathrm{ZY}(\mathrm{DE}+\mathrm{IE}) \\
& =0,666+0,301 \\
& =0,967
\end{aligned}
\end{aligned}
$$

Total Pengaruh Kepuasan Pelanggan

\begin{tabular}{|c|c|c|c|}
\hline \multirow[t]{2}{*}{ TARIABEL } & \multicolumn{2}{|c|}{ KOEFISENJJLL'R } & \multirow[t]{2}{*}{ TOTAL EFFECT } \\
\hline & DIRECTEAFECT & INDIRECT EFFECT & \\
\hline Desain Produk (X) & 0,6660 & 0,301 & 0,967 \\
\hline Keplasan Pelangegan (I) & 0,316 & . & 0,316 \\
\hline
\end{tabular}
terhadap Loyalitas Pelanggan $=\rho z Y$

$\mathrm{DE}=0,316$ (signifikan)

$$
\mathrm{DE}+\mathrm{IE}
$$

$$
\begin{aligned}
\text { Total Pengaruh } & =(\mathrm{DE}+\mathrm{IE}) \\
& =0,316
\end{aligned}
$$

Tabel 7. Total Pengaruh Variabel Eksogen Terhadap Variabel Loyalitas Pelanggan

\section{PEMBAHASAN}

Dari hasil penelitian dapat dilihat bahwa desain produk rumah makan di kota Padang mempengaruhi kepuasan pelanggan dan mempengaruhi loyalitas pelanggan secara langsung dan tidak langsung, maka langkah-langkah yang harus dilakukan oleh manajemen industri rumah makan di kota padang adalah:

1. Mendiferensiasikan Produk.

Didalam upaya untuk mende ferensiasikan produk sebuah rumah makan adalah dengan membuat desain produk yang sesuai dengan keinginan serta harapan dari pelanggan atau konsumen. 
Memberikan produk yang berkualitas lebih tinggi dan bervariasi dari pesaing secara konsisten. Karena kualitas pengalaman dan kepercayaan rumah makan dipertanyakan oleh pelanggan, karena memiliki pelanggan berarti memiliki konsekuensi:

a. Pelanggan rumah makan umumnya lebih tergantung pada promosi dari mulut kemulut daripada iklan jenis lainnya. Pelanggan yang puas dengan produk yang dihadirkan oleh rumah makan akan bercerita ke orang lain.

b. Para pelanggan sangat mengandalkan biaya yang telah dikeluarkan, dan petunjuk fisik, ataupun melihat secara langsung produk yang dihadirkan di rumah makan untuk menilai kualitas produk rumah makan.

c. Jika pelanggan merasa puas, mereka sangat setia pada rumah makan, dan akan menjadi pelanggan tetap.

Dari ketiga hal terebut, rumah makan harus meningkatkan differensiasi produk mereka, baik itu cita rasa, keragaman, cara penyajian, kualitas pelayanan mereka serta produktivitas mereka. Kuncinya adalah dalam mendesain produk dan atribut produk yang dibuat haruslah disesuaikan dengan kebutuhan dan keinginan pelanggan/konsumen, karena produk yang dibuat dimulai dari kebutuhan pelanggan/konsumen dan berakhir pada pelanggan/konsumen, hal ini berarti bahwa citra kualitas produk yang baik bukanlah berdasarkan sudut pandang rumah makan, melainkan berdasarkan persepsi atau sudut pandang pelanggan atau konsumen, karena pelanggan atau konsumen adalah pihak yang mengkonsumsi dan menikmati produk tersebut, sehingga merekalah yang akan menentukan kualitas produk.

Jadi, kunci keberhasilan industri rumah makan adalah pada karyawan yang berkompeten yang akan langsung melayani pelanggan atau konsumen, hal ini dapat tercipta dengan proses rekrutment, pelatihan, dan pengembangan karyawan dalam rangka membangun dan menciptakan kepercayaan dari pelanggan/konsumen terhadap rumah makan. Dalam hal ini terdapat tiga hal yang dilakukan oleh industri rumah makan untuk meningkatkan serta mengendalikan kualitas produk.

a) Investasi dalam seleksi dan pelatihan personel yang baik.

Dalam hal ini perusahaan industri rumah makan mengeluarkan dana yang besar untuk melatih karyawannya dalam mendesain dan menyediakan produk yang baik dan menarik, sehingga seorang pelanggan/konsumen dapat menemukan karyawan yang ahli dan ramah.

b) Standarisasi proses pelaksanaan desain produk dan dalam memproduksi produk.

Hal ini dapat dilakukan dengan jalan menyiapkan suatu blueprint produk yang menggambarkan peristiwa atau event dan proses produk dalam suatu diagram alur, dengan tujuan untuk mengetahui faktorfaktor potensial yang dapat menyebabkan kegagalan dalam produk tersebut.

c) Melakukan pemantauan kepuasan pelanggan atau konsumen.

Lewat sistem saran dan keluhan, survei kepada pelanggan atau konsumen, dan belanja perbandingan, sehingga pelayanan yang kurang dapat dideteksi dan diperbaiki.

2. Manajemen Perusahan harus memahami apa yang diinginkan pelanggan/konsumen.

Manajemen rumah makan harus mengerti apa yang pelanggan/konsumen harapkan dalam suatu pelayanan produk dan bagaimana bisa menyediakan kualitas service yang maksimal. Sebagai contoh, manajemen menetapkan suatu sistem bahwa untuk waktu tunggu atau waktu untuk melayani pelanggan/konsumen di meja makan, termasuk pelayanan lainnya dalam waktu tidak lebih dari 15 menit.

Tetapi kenyataannya pelanggan/ konsumen sudah mulai resah dan mengomel setelah 10 menit, ini berarti sistem yang ditetapkan oleh manajemen menyebabkan pelanggan atau konsumen tidak puas. Mungkin saja manajemen berpikir bahwa waktu 15 menit itu merupakan waktu yang singkat tetapi tidak demikian dengan pelanggan atau konsumen. Dari sini 
manajemen belajar bahwa waktu yang tepat bukan 15 menit tapi 10 menit.

3. Manajemen meningkatkan sistem yang akan memenuhi keinginan pelanggan/konsumen.

Harus ada komitmen yang kuat dari rumah makanan untuk memberikan service quality yang maksimal, meningkatkan kemampuan untuk memahami persepsi pelanggan atau konsumen, adanya standarisasi tugas, dan manajemen harus mempunyai tujuan yang jelas.

Beberapa perusahaan kebanyakan hanya melihat profit jangka pendek saja dan tidak berkeinginan untuk investasi dengan meyediakan modal yang cukup untuk pengembangan karyawan dan peralatanperalatan, inilah yang menyebabkan terjadinya masalah service quality.

Sebagai contoh, manajer rumah makan yang hanya menganggarkan biaya persediaan tisu yang secukupnya untuk tiap meja di rumah makan, dan tidak memikirkan bila persediaan tisu tersebut menyusut/berkurang karena hilang atau rusak. Kemudian ada pelanggan/konsumen yang menginginkan tisu tambahan dan memintanya kepada karyawan, dan karyawan meminta maaf, bahwa pihak rumah makan tidak mempunyai persediaan tisu lagi. Manajemen rumah makan tahu bahwa persediaan tisu sedikit tapi pemilik rumah makan tidak mau menginvestasikan uangnya atau tidak mempunyai uang yang cukup untuk membeli perlengkapan-perlengkapan tersebut. Contoh lainnya, dimana untuk melayani pelanggan atau konsumen dibutuhkan 2 orang karyawan tetap, tetapi pemilik tidak mau mengeluarkan tambahan uang untuk menambah karyawan baru, sehingga pelanggan harus menunggu untuk dapat dilayani yang pada akhirnya akan menyebabkan atau menimbulkan rasa ketidakpuasan dan ketidaknyamanan dari pelanggan atau konsumen.

4. Karyawan harus sanggup atau mempunyai kemauan untuk memberikan service yang maksimal.

Ketika karyawan rumah makan dan pelanggan/konsumen berinteraksi, karyawan diharapkan untuk bisa menunjukkan sikap yang ramah dan penuh senyum, tegur sapa serta dapat membantu menyelesaikan masalah-masalah, keinginan-keinginan, dan keluhan-keluhan dari pelanggan/konsumen, jika tidak maka pelanggan akan merasa tidak puas.

Untuk mengurangi atau meminimalkan terjadinya ketidakpuasan pelanggan/konsumen maka penting sekali peranan dari manajemen mulai dari perekrutan karyawan, pelatihan, pemantauan kondisi kerja karyawan dan peningkatkan sistem penghargaan kepada karyawan yang berprestasi.

5. Menepati janji yang telah dijanjikan kepada pelanggan/konsumen.

Contohnya, bagian/divisi marketing mempromosikan bahwa pelanggan/konsumen yang baru jadi langganan catering akan mendapat hadiah dan menerima pelayanan yang sangat memuaskan, dan itu harus ditepati sesuai dengan yang dipromosikan.

6. Konsistensi dari pihak manajemen

Sebagai contoh, pada awalnya untuk biaya antar/ongkos kirim makanan sudah dimasukkan kedalam harga total makanan tetapi ketika pelanggan atau konsumen melakukan transaksi, ongkos kirim tetap dikenakan.

Seharusnya ada aturan yang jelas mengenai hal biaya administrasi tersebut sehingga terjadi konsistensi mengenai apa yang berlaku di sebuah rumah makan. Demikian juga dengan kebijakan-kebijakan dan ketentuan-ketentuan lainnya yang menyangkut pelayanan terhadap pelanggan atau konsumen harus ada konsistensi.

\section{Create Constancy of Purpose}

Sama seperti sebuah bangunan yang membutuhkan pondasi yang kuat dan kokoh demikian pula sebuah organisasi service harus didasarkan pada tujuan dan visi yang kuat, jelas dan konseptual. Hal-hal ini dibangun dengan memperhatikan apa yang diinginkan dan dipikirkan oleh pelanggan/konsumen. Dengan demikian kita dapat menggunakannya sebagai standar 
untuk mengukur tindakan-tindakan apa yang seharusnya dilakukan dan tidak dilakukan.

Dengan adanya tujuan yang jelas karyawan dapat melakukan pekerjaannya dengan lebih baik dan terarah yang pada akhirnya akan memuaskan pelanggan atau konsumen dengan memberikan kualitas produk yang prima, dengan desain produk yang sesuai dengan harapan pelanggan/konsumen.

Tujuan dan misi visi yang telah dibuat akan menjadi sia-sia bila manajemen tidak konsisten dalam menjalankannya. Oleh karena itu manajemen harus selalu konsisten dengan apa yang telah dirancangkannya dan di desainnya.

\section{Cease Reliance on Inspection}

Oleh karena di bisnis rumah makan sebagai produk service diberikan secara simultan antara produksi dan konsumsinya maka tidaklah mungkin bagi manajer untuk menginspeksi tiap produk service yang diberikan. Oleh karena itu manajer harus memberikan kepercayaan penuh kepada karyawannya untuk melakukan segala sesuatunya dengan benar, termasuk dalam mendesain produk yang akan dihidangkan.

\section{Remove Barriers}

Manajer mempunyai tanggung jawab untuk membangun cara-cara yang dapat membuat karyawan melakukan pekerjaannya dengan benar. Terkadang kesalahankesalahan yang terjadi bukan karena manusianya tapi karena sistemnya. Untuk menghilangkan rintangan-rintangan yang ada, manajemen dapat mengidentifikasi dan mengeliminasi tugas-tugas yang sebenarnya tidak diperlukan sehingga dapat menghemat waktu dan tenaga untuk digunakan tugastugas lain yang lebih penting dan berharga. Selain itu manajemen dapat mencoba untuk mencari, mendesain dan menciptakan tugastugas baru yang dapat memberikan tambahan nilai-nilai baru bagi pelanggan/konsumen.

\section{Practice Leadership}

Dalam menjalankan suatu organisasi diperlukan seorang pemimpin/manajer yang mempunyai visi dan mempunyai jiwa kepemimpinan sehingga dapat mengatur segala sesuatunya berjalan dengan lancar dan menghasilkan profit. Pemimpin yang baik dapat menjamin bahwas karyawannya telah melakukan pekerjaannya dengan benar dan membuat karyawannya dapat bekerjasama untuk mencapai tujuan yang telah ditetapkan manajemen.

\section{Educate and Train}

Pendidikan dan pelatihan merupakan prioritas utama bagi semua perusahaan khususnya rumah makan untuk dapat mencapai service prima yang memuaskan. Perusahaan rumah makan tidak bisa hanya menginvestasikan uangnya di fasilitasfasilitas fisik saja tapi juga harus menginvestasikan dana dan waktu untuk mengembangkan sumber daya manusianya.

Rumah makan tidak akan mendapatkan hasil yang memuaskan tanpa adanya pendidikan dan pelatihan yang cukup untuk karyawannya. Bila manajemen berpikir bahwa pendidikan dan pelatihan butuh biaya yang mahal maka bila terjadi kelalaian/kesalahan dari karyawan yang akan berakibat pada kehilangan pelanggan, maka harga yang harus dibayar bisa lebih mahal.

\section{Build Long-Term Business Relationships}

Setiap karyawan perlu dibantu karyawan lainnya untuk melakukan mendesain dan menciptakan produk, maka perusahaan juga membutuhkan perusahaan atau organisasi lain untuk mencapai tujuan dan misinya dengan membangun hubungan bisnis yang bersifat jangka panjang. Sebuah rumah makan perlu sekali membangun hubungan bisnis dengan mitra, saingan dan pelanggan/konsumen.

Selain itu dengan membangun hubungan atau relasi bisnis yang berkesinambungan dengan perusahaan atau organisasi lain akan membuat rumah makan dapat bersaing dengan para kompetitornya.

\section{Take Positive Action}

Ini adalah hal yang paling penting dan mudah dilakukan tapi sering dilupakan dan diabaikan. Manajemen dalam mendesain produk yang akan diproduksi harus melakukan pendekatan yang proaktif dan inovatif dengan ide-ide yang lebih baik untuk dapat memenuhi keinginan dan kebutuhan 
pelanggan/konsumen dengan selalu memunculkan pertanyaan-pertanyaan :

- Seperti apa yang dapat saya lakukan untuk pelanggan/konsumen?

- Apa yang pelanggan/konsumen butuhkan?

- Bagaimana saya dapat menyenangkan pelanggan/konsumen?

Keuntungan Desain Produk yang tepat kepada rumah makan diantaranya :

1. Mempertahankan Pelanggan/konsumen.

Pelanggan/konsumen yang merasa puas dengan pelayanan yang diberikan oleh sebuah rumah makan akan memberitahukannya kepada orang lain dan sulit untuk membuatnya untuk pindah ke tempat lain.

2. Mempertahankan karyawan-karyawan yang berkualitas.

Karyawan-karyawan yang berkualitas akan lebih menyukai perusahaan tempatnya bekerja dijalankan dengan baik dan menghasilkan produk yang berkualitas karena mereka tidak menginginkan untuk selalu dikomplain oleh pelanggan/konsumen karena produk yang di desain tidak berkualitas.

3. Mengurangi biaya-biaya.

Dengan diberikannya service atau pelayanan yang lebih memuaskan kepada pelanggan/konsumen, pihak manajemen tidak perlu mengeluarkan biaya ekstra untuk kesalahan-kesalahan yang sering dibuat oleh karyawan.

4. Meningkatkan laba perusahaan.

Dengan diberikannya service quality yang maksimal kepada pelanggan akan membuat pelanggan/konsumen merasa puas. pelanggan/konsumen yang merasa puas ini pasti akan memberitahukan kepada orang lain, sehingga banyak orang yang akan datang dan belanja di rumah makan tersebut yang pada akhirnya sangat membantu perusahaan dalam meningkatkan laba.

\section{SIMPULAN}

Nilai R Square pada output SPSS menunjukan bahwa variabel desain produk mampu menjelaskan variabel kepuasan pelanggan sebesar $91,2 \%$, sedangkan sisanya sebesar $8,8 \%$ dipengaruhi oleh variabel/faktor di luar penelitian. Dimana nilai $\mathrm{R}=0,955$ artinya hubungan antara desain produk terhadap kepuasan pelanggan adalah kuat yaitu sebesar 95,5\%. nilai sig. 0,000 (< $0,05)$, jadi memang terdapat pengaruh yang signifikan antara desain produk dengan kepuasan pelanggan. Hasil koefisien jalur antar variabel dan analisis regresi variabel penelitian, dimana nilai koefisien $\rho$ Desain Produk - Kepuasan Pelanggan adalah 0,955.

Tabel Model Summary menunjukan nilai $\mathrm{R}$ Square sebesar 0,946, ini berarti variabel desain produk dan kepuasan pelanggan mampu menjelaskan variabel loyalitas pelanggan sebesar 94,6\%, sedangkan sisanya sebesar 5,4\% dipengaruhi oleh variabel/faktor di luar penelitian. Dimana nilai $\mathrm{R}=0,973$ artinya hubungan antara desain produk dan kepuasan pelanggan terhadap loyalitas pelanggan adalah kuat yaitu sebesar 97,3\%. Desain produk terhadap loyalitas pelanggan memperlihatkan nilai sig. $0,000(<0,05)$, ini berarti terdapat pengaruh yang signifikan antara desain produk terhadap loyalitas pelanggan. Variabel kepuasan pelanggan terhadap loyalitas pelanggan adalah 0,000 $(<0,05)$, dimana menunjukan pengaruh yang signifikan antara kepuasan pelanggan dengan loyalitas pelanggan. Dari hasil koefisien jalur antar variabel dan analisis regresi variabel penelitian, ditemukan nilai koefisien $\rho$ Desain Produk - Loyalitas Pelanggan adalah 0,666 , dan nilai koefisien $\rho$ Kepuasan Pelanggan - Loyalitas Pelanggan adalah 0,316 .

\section{DAFTAR RUJUKAN}

Abu dan Cholid. 2001. Metodologi Penelitian. Bumi Aksara. Yogyakarta.

Algifari. 1997. Statistik Induktif untuk Ekonomi dan Bisnis. UPP AMP YKPN. Yogyakarta.

Swastha, Basu dan Irawan. 2001. Manajemen Pemasaran Modern. Yogyakarta : Liberty.

Swastha, Basu dan T. Hani Handoko. 2001. Manajemen Pemasaran Analisis 
Perilaku Konsumen. Edisi Pertama. Yogyakarta : BPFE.

Djarwanto dan Pangestu Subagyo. (2000).

Statistik Induktif. Yogyakarta : BPFE.

Hadi. 1993. Analisa Butir untuk Instrumen.

Edisi Pertama. Penerbit Andi Offset.

Yogyakarta.

Kotler, Philip dan Armstrong. 2001. Prinsip-

Prinsip Pemasaran. (Damos

Sihombing Terjemahan). Edisi

Kedelapan. Jilid I. Jakarta : Erlangga.

Buku asli diterbitkan tahun 1996.

Kotler, Philip. (1997). Manajemen

Pemasaran Analisa. Perencanaan.

Implementasi dan Kontrol. (Hendra Teguh Terjemahan). Jakarta : Prehalindo. Buku asli diterbitkan tahun 1996.

Marsum. 1991. Restoran dan Segala Permasalahannya. Edisi Pertama. Andi Offet. Yogyakarta.

Masri dan Sofian. 1989. Metode Penelitian Survei. Edisi Revisi. Penerbit LP3ES. Jakarta

Nazir. 1988. Metode Penelitian. Cetakan 3. Ghalia Indonesia. Jakarta.

Santoso. 2000. Pengolahan Data SPSS. Elex Media Komputindo. Jakarta.

Sardiman. 1999. Interaksi dan Motivasi Belajar Mengajar. Cetakan Ketiga. Jakarta : Rajawali.

Subagyo. 1995. Statistik Deskriptif. Edisi 3. Penerbit BPFE. Yogyakarta.

Sugiono. 1999. Metode Penelitian Bisnis. Bandung : CV. Alfabeta.

Suharyani dan Moh. Imam Teguh Rianto. 2001. Modul Pengolahan Data Elektronik : Yogyakarta.

Hadi, Sutrisno. 2000. Analisis Butir Untuk Instrumen Angket dan Skala Nilai dengan Basica. Yogyakarta : Andi Offset.

Tjiptono, Fandy. 1995. Strategi Pemasaran. Edisi Pertama. Andi Offset. Yogyakarta. 